\title{
NOTES ON JUVENAL, APUlEIUS, Etc.
}

IN the Sixteenth Satire, the first topic Juvenal takes up in detail is the impossibility of obtaining satisfactory legal redress from the praetorians. The account has two divisions: (I) you will have a bad time yourself in the military court, (2) and what friend will come to support you?

This second part, beginning at line 25 , reads at present thus:

'quis tam procul absit ab urbe praeterea, quis tam Pylades, molem aggeris ultra ut ueniat? lacrimae siccentur protinus, et se excusaturos non sollicitemus amicos.

'Da testem,' iudex cum dixerit, audeat ille,' etc.

The logic of the whole passage seems to demand at the very beginning of this second division a clear intimation that there is a second division and that it begins here. What is needed is a mention of the friend (at present implied only by Pylades in line 26), and of what he would do when he had got outside the city. In the received text there is no hint that he is to support the plaintiff in court until line 29 (da testem) or less definitely line 28 .

Can we then by a slight change make the first short question of the second part (quis ... praeterea ?) convey all that is made explicit in the following lines? The simplest method is to read

quis tam procul ADSIT ab urbe praeterea?

Merely 'leaving the city' in any direction (absit) is not enough. 'Molem aggeris ultra' gives us a clue. I take 'beyond the mound' as possibly having been a common phrase in Rome for 'the praetorian camp,' as to us 'over the herring-pond' means America. The map of Rome shows that a man passing the agger would probably be bound for the camp.

If 'adsit' is correct, we find Juvenal in line 26 expanding his thought, as is his custom: he analyses the idea in adsit (a friend supporting a man in court) into Pylades, the friend, who ultra molem aggeris uenit, i.e. enters the Praetorian camp and court.

Procul and $a b$ on either side would well account for the attraction of $a d$ into absit. The phrase 'to appear in support of any one far from somewhere' is so uncommon that analogous instances do not readily present themselves, by which it might be shewn that adesse has a strong enough character to 
stand unaffected by such a term as procul. However, Val. Max. iv. 2. 7 . (Cornelia) 'pertinacissime absenti adfuit' shews that such a phrase would be quite possible.

APulerus' Metamorphoses, ii. 5 (ed. Helm). Maga primi nominis et omnis carminis sepulchralis magistra creditur.

Surely muminis. To say 'she is believed to have a great reputation' is absurd: she either had or had not.

Numen, it is true, is generally used of gods, but 'tribuitur aliquando et hominibus qui potentia, dignitate, dominatu, deorum quodammodo uim in terris habent' (Facciol. and Forcell., s.v.). Thus it is used not only of the Senate (in Cic. and Livy) but of dead friends or relations: 'per numen Drusillae deierauit,' Suet. Cal. 24, and could well be used of the supernatural powers delegated to a witch.

ii. 29. Iam tumore pectus extolli, iam salubris uena pulsari, iam spiritu corpus impleri.

The symmetrical arrangement of these clauses is noticeable. Each consists of ablative, nominative and infinitive, in the same order-with the sole exception of salubris. 'Vena salubris' is intelligible, though a very unlikely phrase: (saluber, meaning 'in healthy condition,' is usually found only with corpus). Much better sense is attained, and the clause made to coincide in form with the other two, by reading salebris, i.e. a perceptible beating of the pulse. For such a use cf. Val. Max. ix. 12, ex. 6, 'guttur salebris spiritûs praegrauauit,' and id. vi. 9, ex. 5. The corresponding verb is as common in this sense as the noun is uncommon: e.g. Ov. $M$. x. 289 , 'saliunt temptatae pollice uenae,' and id. Her. xx. 139.

x. 2. ... filium probe litteratum atque ob id consequenter pietate modestia praecipuum.

Several scholars have proposed to insert et between pietate and modestia, where it could easily have been lost. Beside this correction, is not $o b$ id a marginal explanation of the uncommon consequenter, wrongly inserted by some copyist into the text? Both phrases cannot stand.

Augustine, Confess. ix. 9. 20 (Teubner). Socrum etiam suam primo susurris malarum ancillarum aduersus se irritatam sic uicit obsequiis ... ut illa ultro filio suo medias linguas famularum proderet, quibus inter se et nurum pax domestica turbabatur.

Medias linguas is ridiculous. Read maledicas, i.e. the 'susurri malarum ancillarum' above mentioned.

S. T. Collins. 